\title{
Representing crop rotations in life cycle assessment: a review of legume LCA studies
}

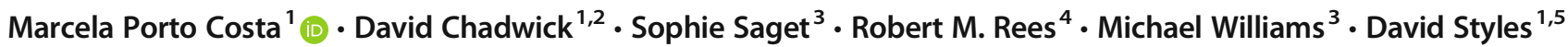

Received: 11 February 2020 / Accepted: 12 August 2020 / Published online: 22 August 2020

(C) The Author(s) 2020

\begin{abstract}
Purpose There is an imperative to accurately assess the environmental sustainability of crop system interventions in the context of food security and climate change. Previous studies have indicated that the incorporation of legumes into cereal rotations could reduce overall environmental burdens from cropping systems. However, most life cycle assessment (LCA) studies focus on individual crops and miss environmental consequences of inter-annual crop sequence and nutrient cycling effects. This review investigates state-of-the-art representation of inter-crop rotation effects within legume LCA studies.

Methods A literature review was undertaken, starting with a search for all peer-reviewed articles with combinations of 'LCA', 'legumes' and 'rotations' or synonyms thereof. In total, 3180 articles were obtained. Articles were screened for compliance with all of the following requirements: (i) reporting results based on LCA or life cycle inventory methodology; (ii) inclusion of (a) legume(s); (iii) the legume(s) is/are analysed within the context of a wider cropping system (i.e. rotation or intercropping). Seventy articles satisfying these requirements were analysed.

Results and discussion We identified three broad approaches to legume LCA. Most studies involved simple attributional LCA disregarding important interactions across years and crops in rotations. $\mathrm{N}$-fertilizer reduction through legume residue $\mathrm{N}$ carryover is either disregarded or the benefit is attributed to the following crop in such studies, whilst $\mathrm{N}$ leaching burdens from residues are usually attributed to the legume crop. Some studies applied robust allocation approaches and/or complex functional units to enable analysis of entire rotation sequences, accounting for nutrient cycling and break crop effects. Finally, a few studies applied consequential LCA to identify downstream substitution effects, though these studies did not simultaneously account for agronomic effects of rotational sequence changes.

Conclusions We recommend that LCA studies for legume cropping systems should (i) evaluate entire rotations; (ii) represent nitrogen and ideally carbon cycling; (iii) for attributional studies, define at least two functional units, where one should encompass the multifunctional outputs of an entire rotation and the other should enable product footprints to be calculated; (iv) for CLCA studies, account for both agronomic changes in rotations and markets effects; (v) include impact categories that reflect hotspots for agricultural production.
\end{abstract}

Keywords Legumes $\cdot$ Crop rotations $\cdot$ Functional units $\cdot$ Allocation $\cdot$ Multi-functionality $\cdot$ Nitrogen cycling

Responsible editor: Thomas Jan Nemecek

Electronic supplementary material The online version of this article (https://doi.org/10.1007/s11367-020-01812-x) contains supplementary material, which is available to authorized users.

Marcela Porto Costa cmarcelaporto@gmail.com

1 School of Natural Sciences, Bangor University, Bangor, Wales LL57 2UW, UK

2 Interdisciplinary Research Centre for Agriculture Green Development in Yangtze River Basin, Southwest University, Chongqing, China
3 Dublin Department of Botany, School of Natural Sciences, Trinity College Dublin, Dublin, Ireland

4 Scotland's Rural College, West Mains Road, Edinburgh EH9 3JG, UK

5 Plant and AgriBioSciences Centre, Ryan Institute, National University Ireland Galway, Galway, Ireland 


\section{Introduction}

Sustainable and resilient agriculture is critical to tackling climate change whilst delivering food security and reducing dependence on finite resources such as fossil fuels (FAO 2018). Within the European Union, the Common Agricultural Policy (CAP) is a major driving force that influences practice in the agricultural sector (Europe Commission 2018). Grain legumes are supported under CAP within ecological focus areas, agrienvironmental schemes and greening requirements, and also promoted within organic farming (Behera et al. 2012). Despite being encouraged by these policies, Zander et al. (2016) argue that legume system development is limited by other stronger market and policy incentives, such as the policies that boost oilseed rape designated to biofuel production (European Parliament 2009). Current European cropping systems rarely include legumes in their rotations. Only $1.5 \%$ of arable land is dedicated to cultivating legumes, compared with $14.5 \%$ worldwide (FAOStat 2016). This situation contributes to a deficit of $70 \%$ of high-protein crop commodities for animal feed in Europe, which is compensated by imports from North and South America (Watson et al. 2017). In addition to raising concerns over food security, large-scale import of protein to the EU (European Parliament 2018), especially soybean, is related to environmental concerns such as deforestation and associated habitat loss and greenhouse gas (GHG) emissions (Nemecek et al. 2008). In this context, one of the priorities for European policy is to reduce the dependence on imported protein (European Commission 2018b).

Legumes are an important source of protein for feed and food. These crops have the ability through symbiotic microbial associations to fix atmospheric nitrogen $(\mathrm{N})$ which is eventually returned to the soil, leading to a reduction in $\mathrm{N}$ fertilization needs, not only for their own production but also for the following grain crop in the order of $60 \mathrm{~kg}$ of N ha ${ }^{-1}$ annually (Preissel et al. 2015). These values can vary according to the soil and cultivar species, for example peas can provide a $\mathrm{N}$ credit of $40-49 \mathrm{~kg} \mathrm{~N} / \mathrm{ha}$ for the following wheat crop (Plaza-Bonilla et al. 2017). Yields of subsequent cereal crops have been measured at 0.2 to a $1.6 \mathrm{t}$ /ha greater following legumes, and agrochemical use 20-25\% lower (Zander et al. 2016). Hence, incorporating legumes into typical cereal rotations across Europe could bring benefits in terms of reducing environmental burdens across multiple crops and derived products, with significant potential to reduce GHG emissions (especially from fertiliser production and use), acidification, terrestrial and aquatic ecotoxicity burdens, among others (Nemecek et al. 2008). However, a possible trade-off of legume cultivation is higher rates of nitrate leaching (Nemecek et al. 2008; Watson et al. 2017). Overall, agricultural experiments and life cycle assessment (LCA) studies suggest that increasing legume production in Europe could be an effective strategy to improve protein security whilst reducing environmental impacts (Nemecek et al. 2008; Karlsson et al. 2015; Stoate et al. 2015; Plaza-Bonilla et al. 2018).

From an economic perspective, legumes are typically regarded as inferior to cereals (Foyer et al. 2016). This perception is challenged by Preissel et al. (2015) who studied 53 legume rotation models in Europe and concluded that $66 \%$ of them present competitive gross margins compared with nonlegume systems. In addition, Zander et al. (2016) highlight the importance of external effects of legumes which are usually not taken into economic consideration, such as the enhancement of biodiversity and improvement of soil quality and soil organic carbon specifically (Yao et al. 2017; Goglio et al. 2018b).

LCA consists of analysing the environmental aspects of a product or service over the entire value chain of production, use and end-of-life, considering upstream and downstream processes (ISO 14040 2006). According to Klöpffer (2003), 'Life cycle thinking is the prerequisite of any sound sustainability assessment'. The author cautions that modifying a specific production step based on information for only one impact category can bring about negative consequences for other impact categories and other steps of the system. When applied to agriculture, many LCA studies draw boundaries or focus around a single crop or its (co-)product(s) (Bevilacqua et al. 2014; Hedayati et al. 2019). Thus, since the focus of these studies is on one cropping cycle, important interactions across crops and over years within crop rotations may be neglected. Recently, numerous authors have emphasised the importance of analysing whole cropping systems rather than individual crops in those systems (Brankatschk and Finkbeiner 2015; Brankatschk 2018; Peter et al. 2017). Therefore, new LCA methods, calculators and approaches are being proposed to evaluate the environmental impacts of changes to agricultural systems (Brankatschk and Finkbeiner 2015; Stoate et al. 2015; Reckling et al. 2016; Brankatschk 2018; Peter et al. 2017; Carof and Godinot 2018; Goglio et al. 2018b).

Representation of legume rotations are just one example of cropping system challenges in LCA studies. Brankatschk and Finkbeiner (2017) simulate production of wheat bread, cow milk, rapeseed biodiesel and straw for bioethanol by modelling them as discreet annual cultivations or as crop rotations (through attributional LCA), where straw is treated as either a residue or a co-product of the system. Treating straw as a coproduct within rotation LCA, the carbon footprints of bread, milk and rapeseed can be $11 \%, 22 \%$ and $16 \%$, lower, respectively, compared with a simple LCA of an annual cultivation cycle, whilst the footprint of bioethanol can be up to $80 \%$ higher.

This review aims to understand how LCA has been applied to assess legume rotations (rather than legume crops in isolation). More specifically, it investigates how various inter-crop rotation effects are taken into account and the main barriers representing these effects accurately in LCA. To do this, we ask the following questions: 
(i) Which functional units are appropriate for legume rotation systems?

(ii) Where are the optimal system boundaries delineated through space and time (e.g. a single cropping cycle or a crop rotation)?

(iii) How are carbon, nitrogen and wider nutrient cycling effects best represented?

(iv) How and when should allocation be applied?

(v) Which impact categories are most relevant?

\section{Method}

A review was conducted to assess how legume cropping systems are represented in LCA. The literature review was completed in June 2019, based on evaluation of publications from peer-reviewed journals. The search engines used were ScienceDirect and Web of Science. LCA studies for legume rotations and intercropping were assessed by searching the following code: ('life cycle assessment' OR 'carbon footprint' OR 'environmental impact' OR 'environmental footprint') AND ('legume' OR 'pulse' OR 'leguminous' OR 'peas' OR 'chickpeas' OR ‘beans' OR 'lentils' OR 'lupin' OR 'vetch' OR 'alfalfa' OR 'clover') AND ('Rotation' OR 'integration' OR ‘intercropping' OR ‘cropping system' OR ‘farming system'). Next, studies were selected where they matched the theme of LCA for legumes within rotation or intercropping systems by screening for compliance with all of the following requirements: (i) reporting results based on LCA or life cycle inventory methodology; (ii) inclusion of (a) legume(s); (iii) the legume(s) is/are analysed within the context of a wider cropping system (i.e. rotation or intercropping). There was no time restriction, since the number of older articles regarding this subject is limited compared with other themes. Two years was the minimum rotation length considered. Soybean was the only legume crop not included, unless it occurred with other legume varieties in the rotation. This decision was taken as soybean is often grown in industrialised mono-cultures or in very short rotations in major producing countries such as the USA and Brazil (WWF 2014). These systems involve fewer crop interactions and are mostly outside of Europe. Leguminous tree species were also outside the scope. European rotations were the main focus of this study, although Canadian and Australian rotations were also considered, as these countries have a high share of their arable land dedicated to legume cultivation (FAOStat 2016).

The articles obtained were analysed according to their main LCA structure. The first step was to understand the goals of each study and how they were translated into a functional unit. We categorised the functional units according to how many functional variables analysed per study. We further investigated whether these variables were based on independent criteria (e.g. kilogram of product, energetic potential), or combined in a dependent metric where the total amount of product is corrected by a product characteristics such as the fat and protein correct milk value FPCM (European Commission 2018b).

As a second step, the system boundaries were classified according to the main activities included, and excluded, in the LCA studies. The classification varied from simple to more complex approaches. We investigated which phases of the life cycle were included in each study. For example, from cradle to farm gate (until the harvesting of the grain) where activities associated with extraction and manufacturing of the majority of inputs were considered alongside their use on the farm, but nothing more. The other classification varied according to the activities included after the farm gate (downstream processes), such as transport and storage of grains before processing; the industrial phase (up to industry gate); or distribution and retail of the products. Another classification was added when avoided processes or consequential scenarios were considered, involving the expansion of boundaries to include, e.g. the avoidance of the use of a specific fossil fuel in favour of biodiesel.

We further analysed if the authors explicitly considered any soil organic carbon changes (SOC) or $\mathrm{N}$ fixing, whether by demonstrating the specific amount of $\mathrm{N}$ fixed or by considering any reduction of fertiliser use on the following crop. The penultimate step entailed the study of the allocation methods used in the following instances: (i) between the final products and considered co-products; (ii) allocation of specific upstream processes, such as production of farm machinery; and most importantly, (iii) the allocation of the nutrient flow between legumes and following crops. A final step involved the analysis of the impact categories presented in the studies, including a broad definition to capture critical inventory results, such as land use in square meters per year.

\section{Results}

In total, 3180 studies were obtained as a result of the search. First, studies were screened to discard those that had no relation to the investigated topic. For example, many discarded studies mentioned the word 'pulse' in the context of 'pulse' of emission, or impulse, or the word 'beans' in the context for coffee or cocoa beans. The results also contained studies of microalgae or algae, since they fix atmospheric $\mathrm{N}$ and can be found in feed and food value chains. Following the screening with the aforementioned requirements, only 70 published studies satisfied all the criteria established by the review. Studies that were excluded included those that performed a LCA of an individual legume with no rotation context; performed a review of secondary data, such as meta-analysis; simulated diets through commercial datasets instead of performing a simulation of farm systems; recommend LCA 
Fig. 1 Flow chart describing the sequential screening of articles through application of selection criteria. (i) Reporting results based on LCA or life cycle inventory methodology; (ii) inclusion of (a) legume(s); (iii) the legume(s) is/are analysed within the context of a wider cropping system (i.e. rotation or intercropping)

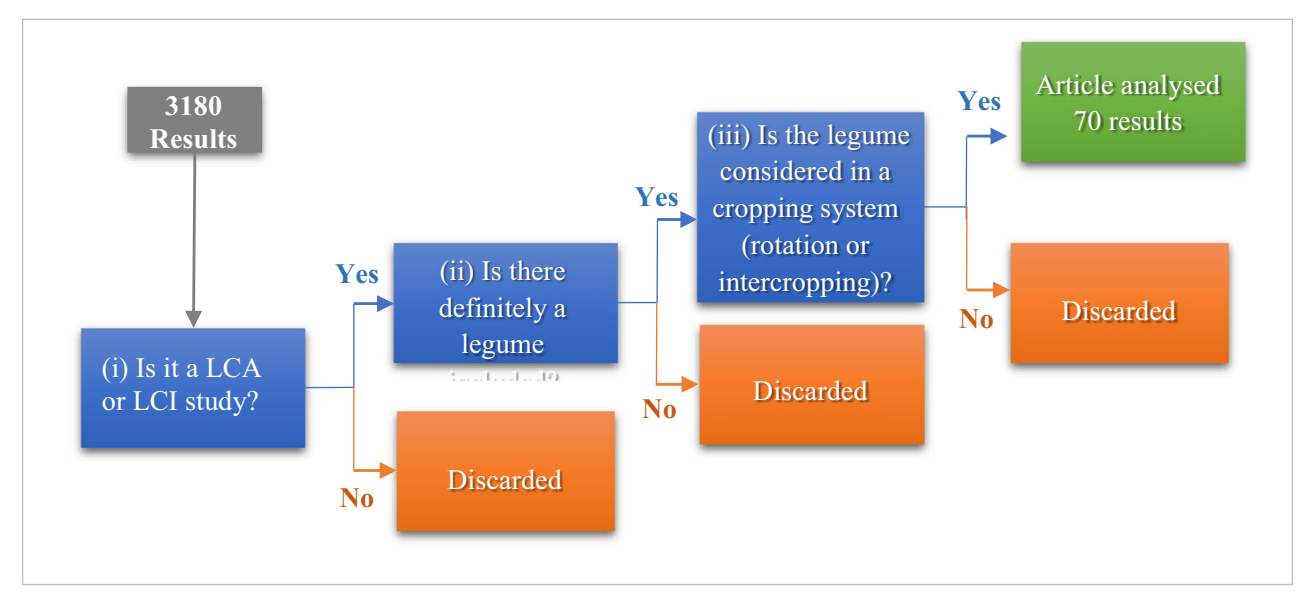

as a next step for further understanding of the topic. The paper selection flow chart, according to the questions aforementioned, can be observed in Fig. 1.

The complete information about the 70 studies mapped in this review is available in appendix 1 .

\subsection{Definition of goal and functional unit}

From our analysis, $44 \%$ of the reviewed articles (31) consider only one functional unit, which is related to a physical aspect of production. Table 1 summarises four main categories of functional unit (FU), and their frequency across reviewed articles. The most common FU encountered (24\%) was related to area, followed by a simple product characteristic such as mass (dry matter of fresh matter), quantity of protein $(\mathrm{kg})$ or gross energy output of determined products (Dalgaard et al. 2006; Nikièma et al. 2011; Knudsen et al. 2014a; Karlsson et al. 2015; Yao et al. 2017; Cai et al. 2018). Among these studies, the main focus was to assess the environmental impact of producing a specific crop within the crop rotation, such as wheat (Barton et al. 2014; Yao et al. 2017) or switchgrass for bioenergy (Ashworth et al. 2015). When study goals went beyond assessment of a single product, to assess rotation level efficiency, the FU most commonly used was based on area and time, such as production quantity from 1 ha over 1 year or over the duration of a rotation cycle. This FU was found in 17 articles (24\%) such as in Nemecek et al. (2008) and Goglio et al. (2018b). This area-time FU is known as a Land Management Functional Unit (Nemecek and Erzinger 2005), where the goal is to maintain agricultural production on the land whilst reducing its environmental impacts - the common unit is everything produced in 1 ha in 1 year.

The remaining 39 articles (56\%) analysed at least two types of FU, with numerous authors proposing that one FU is insufficient to assess multi-product crop rotations (Carranza-Gallego et al. 2018; Hoffman et al. 2018; Reinsch et al. 2018). Almost $20 \%$ of articles (13) analysed three or more types of FU. Nemecek et al. (2008) and Zucali et al. (2018), for instance, applied a productive FU, expressed in $\mathrm{kg}$ DM or gross energy content, an area-based FU, and a financial FU expressed in monetary value (receipts minus direct costs of production). Prechsl et al. (2017) applied the cereal unit (CU), primarily designed for allocation within rotations, as a FU, in addition to mass- and area-based FUs. The CU converts all grain into a common reference unit calculated by the feed energy digestibility for animals (Brankatschk and Finkbeiner 2014).

Nine papers (13\%) presented a FU that combines two simple independent variables, the physical quantity of product with a physical aspect of quality. This is the case for energy studies, which evaluate not only the amount of crop produced
Table 1 Types of functional units encountered in the articles assessed in this review

\begin{tabular}{llc}
\hline Function unit & $\begin{array}{l}\text { Frequency of } \\
\text { occurrence }\end{array}$ & $\begin{array}{l}\text { No. of } \\
\text { articles }\end{array}$ \\
\hline One simple product-based variable (e.g. kg, MJ, protein) & $20 \%$ & 14 \\
One simple area-based variable (e.g. ha) & $24 \%$ & 17 \\
Two simple independent variables (e.g. kg + ha) & $20 \%$ & 14 \\
Three simple independent variables: (e.g. kg + ha +€) & $19 \%$ & 13 \\
$\begin{array}{l}\text { Two dependent variables - product amount and quality aspect of it (such as } \\
\text { milk FPCM }\end{array}$, which considers fat and protein content), rice equivalent & $13 \%$ & 9 \\
$\quad$ (amount and cost of a grain related to rice) & $4 \%$ & 3 \\
\hline Other (multi-variable) & & \\
\hline
\end{tabular}

${ }^{1}$ FPCM: Fat and protein correct milk value (European Commission 2018a) 
but also the gross energy content or the final useful energy generation potential of the material. Dairy studies were included in this review because they explicitly account for legume feed production (Pirlo et al. 2014), usually reporting the mass of milk corrected for protein and fat content as the FU, as recommended by FAO (2016). Some studies convert multiple crop outputs from a rotation into a specific grain equivalent. Alam et al. (2019) converted the mustard crop under rotation into rice equivalent yield (REY). The REY is calculated by the mustard crop yield multiplied by its market price and then divided by the market price of rice, in effect representing an economic revenue FU.

Grönroos et al. (2006), Tuomisto et al. (2012) and Röös et al. (2016) were the only studies captured by this review that propose a multi-variable FU, where multi-functionality is addressed by integrating a specific portfolio of required outputs into a single FU. They proposed a composition of different products; thus, the function of the systems under analysis is achieving an exactly defined proportion of different products, such as, for Röös et al. (2016), a drink with the function of milk + protein for humans + rapeseed oil and protein feed corresponded to an amount of grain legumes + grazing of 49 ha of semi-natural grasslands. Similarly, Tuomisto et al. (2012) proposed $460 t$ of potatoes $+88 \mathrm{t}$ of winter wheat $+60 t$ of field beans $+66 \mathrm{t}$ of spring wheat as functional unit .

Almost all studies (94\%) performed a comparison of products or systems. Accounting LCAs were found in calculators elaborated to generate footprints for particular crops within rotations (Peter et al. 2017; Carof and Godinot 2018; Goglio et al. 2018b). In these studies, the main goal was to quantify and understand the impact of one product or process through its value chain rather than perform a comparison.

\subsection{Approach and definition of the system boundaries}

A majority of studies applied an attributional LCA approach (Rebitzer et al. 2004). Consequential LCA (Ekvall and Weidema 2004) was applied only by Knudsen et al. (2014a) and Karlsson et al. (2015), whilst attributional LCA with consequential scenarios were found in 7 studies $(10 \%)$. These LCA studies simulated substitution and avoided production in supply chains situated outside of the direct cropping system boundaries. In relation to the boundaries adopted, more than twothirds of the reviewed studies (71\%) consist of analyses from cradle to farm gate and therefore included upstream processes such as the manufacture, transport and use of inputs to the farm in addition to farm operations and processes (Table 2). Only $7 \%$ of the studies added activities such as transportation and storage beyond the farm gate, and $9 \%$ include processes up to product manufacture to represent consumable products (Table 2). Some of the studies (4\%) focused only on farm activities and processes, or only accounted for some of the main upstream processes associated with farm inputs (Kristensen
Table 2 Boundaries established by the articles assessed in this review

\begin{tabular}{llc}
\hline Boundaries & $\begin{array}{l}\text { Frequency of } \\
\text { occurrence }\end{array}$ & $\begin{array}{l}\text { No. of } \\
\text { articles }\end{array}$ \\
\hline Cradle to farm gate & $71 \%$ & 50 \\
Cradle to transport or storage & $7 \%$ & 5 \\
Cradle to process, industry gate or retail & $9 \%$ & 6 \\
$\begin{array}{l}\text { Cradle to farm or industrial gate + avoided } \\
\quad \text { emissions of CLCA scenarios }\end{array}$ & $7 \%$ & 5 \\
$\begin{array}{l}\text { Cradle to grave } \\
\text { Farm or farm plus upstream processes for } \\
\text { some main inputs }\end{array}$ & $1 \%$ & 1 \\
\hline
\end{tabular}

et al. 2011; De Vries et al. 2014; Hauggaard-Nielsen et al. 2016). This is very common in studies that calculated only carbon footprints and/or just focus on field measurements (Dalgaard et al. 2006; Hunt et al. 2017; Reinsch et al. 2018). Five studies (7\%) extended the boundaries from farm gate to a wider scenario scale involving multiple farm systems, to calculate possible environmental effects on a larger scale. Karlsson et al. (2015) incorporated a consequential LCA of fava bean use, changing it from the protein feed for dairy cows to processing in a green biorefinery producing ethanol, protein concentrate feed and fuel briquettes, or with the whole crop used as roughage feed. Knudsen et al. (2014a) analysed the consequences of introducing peas and fava beans in European rotations by accounting for reduced production of soybeans outside of Europe. Despite focusing only on GHG emissions, this study addresses key concerns about the wider sustainability of modifications made to globally inter-connected food systems, similarly to Styles et al. (2017).

\subsection{N carryover, carbon sequestration and allocation methods}

Legumes have the ability to fix atmospheric $\mathrm{N}$ and consequently to provide $\mathrm{N}$ to the following crop, reducing the need of external synthetic fertilization (Preissel et al. 2015; Reckling et al. 2016; Watson et al. 2017). The majority of LCA studies of legume rotations (70\%) either explicitly accounted for the amount of $\mathrm{N}$ fixed by legumes using literature estimates or implicitly by a reduction in fertilization of the next crop in rotation sequence (Table 3 ). The $\mathrm{N}$ benefit was not considered in $3 \%$ of the studies, due to lack of reliable data (Prechsl et al. 2017; Hedayati et al. 2019) or because it was judged as irrelevant for the total impact calculation (Knudsen et al. 2014a). For the studies that did not mention any $\mathrm{N}$ fixation or where insufficient information was provided to understand the method (27\%), two options are possible: (i) no $\mathrm{N}$ carryover was accounted for; (ii) $\mathrm{N}$ carryover was implicitly accounted for based on, e.g. primary activity data for fertilizer application to the following crop. 
Table 3 Numbers of articles reviewed that account for $\mathrm{N}$ carryover effects and carbon sequestration

\begin{tabular}{|c|c|c|c|c|}
\hline & \multicolumn{2}{|c|}{$\mathrm{N}$ fixing assessed? } & \multicolumn{2}{|c|}{ Soil organic carbon change assessed? } \\
\hline & $\begin{array}{l}\text { Frequency of } \\
\text { occurrence }\end{array}$ & No. of articles & $\begin{array}{l}\text { Frequency of } \\
\text { occurrence }\end{array}$ & No. of articles \\
\hline Yes & $70 \%$ & 49 & $39 \%$ & 27 \\
\hline No & $3 \%$ & 2 & $20 \%$ & 14 \\
\hline Not clear/not mentioned & $27 \%$ & 19 & $41 \%$ & 29 \\
\hline
\end{tabular}

Soil organic carbon (SOC) sequestration is often not taken into account in agriculture LCAs, mainly because the crop will be processed and most of the biogenic carbon sequestered in the plant tissue during growth will return to the atmosphere (Rees et al. 2005). However, SOC is known to change slowly over long periods in cropping systems (Ostle et al. 2009; Smith 2014). A number of studies indicate long-term SOC decline in European arable soils, especially because of short and cereal-dominated rotations and management practices such as full, frequent ploughing and straw removal (Smith 2004). The potential for SOC accumulation depends on the quality and quantity (biomass) of residues (Watson et al. 2017). Even though legumes are known to produce more Nrich residues compared with cereals (Meyer-Aurich et al. 2006; Carranca et al. 2009; Begum et al. 2014; Laudicina et al. 2014; Tosti et al. 2014), they typically produce less residue biomass (Meyer-Aurich et al. 2006; Begum et al. 2014). Some studies point to a SOC decrease when a legume crop is introduced into cereal-dominated systems, due to the smaller amount of above and below ground biomass generated by legumes when compared with cereals, such MeyerAurich et al. (2006) who analysed soybean and maize cultivation, and Laudicina et al. (2014) who analysed wheat/ fava bean rotations. However, other studies paint a more complex picture across the many species and cultivars of legumes, which typically produce nutrient-rich residues that decompose more rapidly than cereal residues due to their lower lignin content (Laudicina et al. 2014). The rapid decomposition of legumes contributes a break crop effect, promoting an increase in the following crop yields, which in turn can increase biomass residue inputs (above and below ground), and therefore contribute to a higher equilibrium level of SOC (Drury and Tan 1995). These effects may not be attributed to legumes, but to the high-yielding following crops (e.g. cereals).

In this review, $39 \%$ of studies considered SOC sequestration when calculating global warming potential, whilst $20 \%$ explicitly declared that they did not include it. The remaining $41 \%$ did not mention SOC effects, and presumably did not account for them (Table 3). Yang et al. (2014) state that accounting for carbon sequestration can influence the final carbon footprint by 15 to $20 \%$.

To understand how the potential benefits ( $\mathrm{N}$ fixation and carbon sequestration) and burdens (leaching potential and
GHG emissions) of legume production were distributed within cropping systems, this review also analysed methods of allocation across multiple products from rotations (Last Column of Table 1, Appendix 1). Allocation is defined by ISO as 'partitioning the input or output flows of a process or a product system between the product system under study and one or more other product systems' (ISO 14040 2006). Overall, $46 \%$ of studies do not explicitly mention where and how cultivation burdens may have been allocated across crops within rotation cycles. Some studies mention other aspects of allocation, such as how machinery building aspects were taken into account or how final products such as meat and milk were allocated from dairy production, without specifying the cultivation stage.

According to the ISO standard, allocation should be avoided where possible by subdivision of the system into sub-processes with specific data or by expanding product systems to include the wider functionality of co-products in the main goal of the study (ISO 14044 2006). Where allocation cannot be avoided, a physical relation between the coproducts should be adopted. Economic allocation is recommended when there is no other possibility (ISO 14044 2006). Since the ISO standards were established as a general framework for LCA, there has been a clear effort from scientists to address allocation challenges for cropping systems (Goglio et al. 2012; Barton et al. 2014; Martínez-Blanco et al. 2014). Brankatschk and Finkbeiner (2015) proposed use of the aforementioned CU as a basis for biophysical allocation, based on crop digestible energy content for animals. The CU is applicable when most of the rotation (cereal) outputs are destined for animal feed, but is less relevant when products are destined directly for human consumption, bioenergy generation or use as fibre.

A significant share $(15.5 \%)$ of reviewed papers declare having no co-products, usually those that define an areabased FU or those that define the timeframe as being post harvesting of a previous crop until the harvest of the following crop. Under the latter approach, the burdens and benefits associated with non-harvested legume cover crops, for example, are fully attributed to crop harvested after the legume cultivation (Prechsl et al. 2017; Hoffman et al. 2018), or attributed to multiple following crops harvested after the legume cultivation (Peter et al. 2017). However, if the legume cover crop is 
harvested and leaves the farm boundaries, the $\mathrm{N}$ benefit promoted by the legume crop is fully attributed to the following crop, whilst the leaching is fully attributed to the legume crop (Fig. 2). Thus, the manner in which emission factors and $\mathrm{N}$ carryover credits are often calculated can lead to an attribution of credits and burdens between legumes and subsequent crops that is detrimental to the apparent environmental efficiency of legumes (Brankatschk 2018). Figure 3 shows how allocation methods for carryover nutrients can link the benefits of $\mathrm{N}$ fixation by legume crops with burdens, such as leaching across all crops in the rotation. In this review, nineteen (27\%) of the studies opted for mass, energy or economic allocation. Only two studies (3\%) applied system expansion, and two others (3\%) applied biophysical allocation. In four studies (5.5\% of sample), allocation was applied using more than one method in the sensitivity analysis or through a Nrelation metric. Naudin et al. 2014 evaluate allocation in intercropping systems through (i) mass, based on the yield of each grain, (ii) economic output, (iii) $\mathrm{N}$ allocation, considering the $\mathrm{N}$ yields in grains and (iv) system expansion.

Nemecek et al. (2015) undertook an LCA of 60 crop combinations comparing legume-cereal rotations with cereal rotations. In their study, under the productive FU, the time frame is one agricultural year. Therefore, in order to capture the effects of a rotation, each crop was analysed according to its sequence in the rotation. A cereal crop was considered after a cereal, legume, rapeseed or sunflower crop; thus, the reduction of fertiliser due to $\mathrm{N}$ carryover from the previous crop was computed for each particular case. Additionally, crops cultivated after a catch crop were studied separately. According to the authors, the analysis of a certain crop after each individual possible preceding crop in a rotation can be very resourceintensive. Macwilliam et al. (2014) used a protein FU, enabling all products to be represented in terms of kilogram of protein. In this approach, the rotation is treated as a black box process (inputs and outputs are not specified per crop) and allocation is avoided. The study assesses the impact of introducing pea and lentil into cereal rotations and calculates the nitrous oxide emissions for pulses based on the $\mathrm{N}$ content in below and aboveground biomass.

None of the reviewed articles attributed full credit for avoided fertilisation requirements to the legume crop in the rotation, as recommended by the Australian guidelines (Grant et al. 2019). Those guidelines recommend this approach as the most practical way to separate out the impact of legumes cultivated in rotation with cereals, and specifically propose that $100 \%$ of avoided fertiliser credits in following crops, and $100 \%$ of the leaching (burdens) from the legume crop, and attributed to the legume.

\subsection{Selection of impact categories}

Two-thirds of the reviewed studies (66\%) present the results across only one or two impact categories. Half the studies only reported global warming potential; the remaining $34 \%$ considered more than two impact categories. After global warming

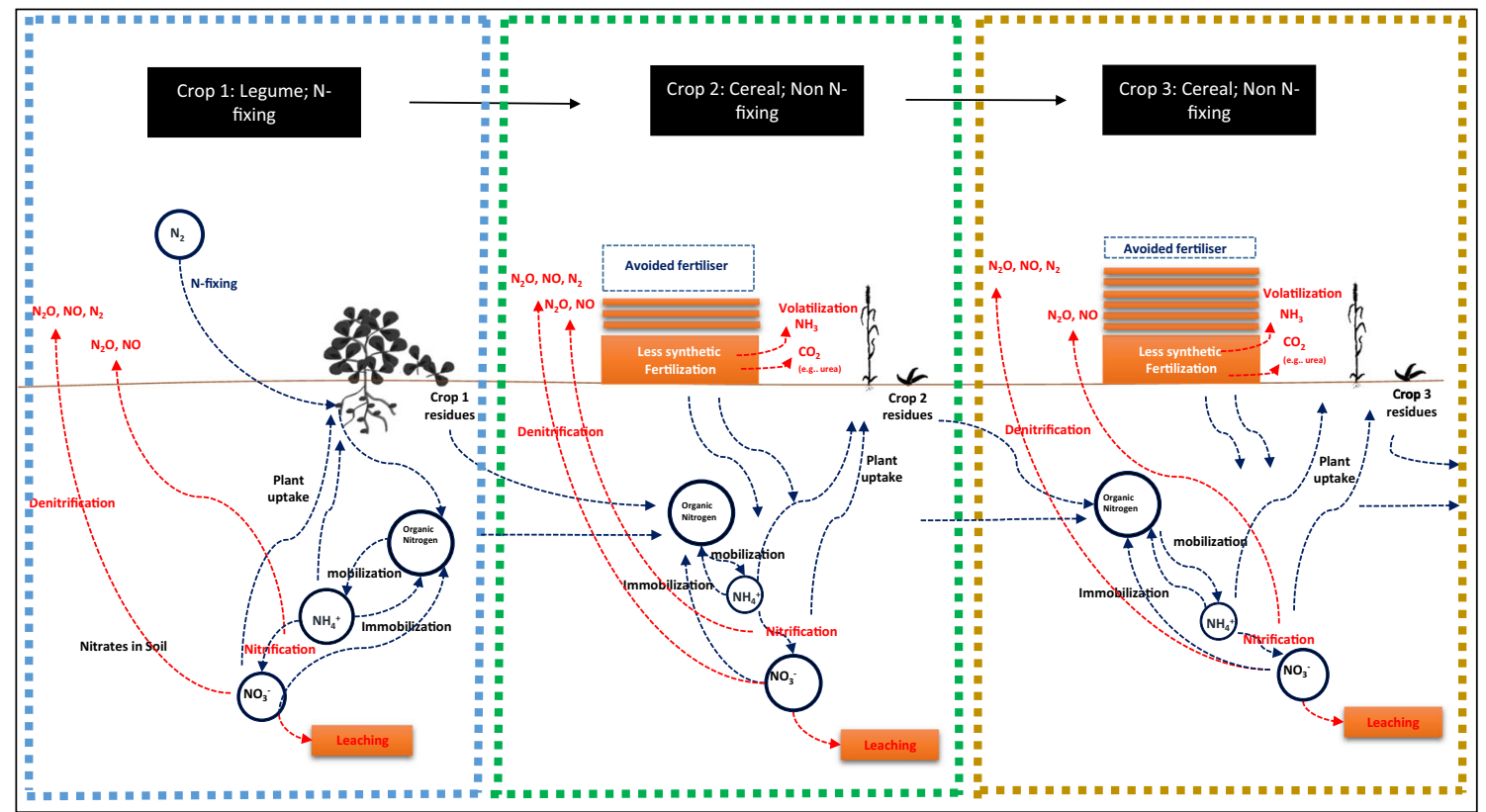

Fig. 2 The nitrogen fixed by a legume crop and the crop residues of legume crop 1 can offer a benefit of reduced fertilization for the following crops in the rotation. If considering typical boundaries adopted by LCA studies, from the soil preparation up to the harvest process of each crop, the reduced fertilizer applications associated with carryover of residue $\mathrm{N}$ from crop 1 translate into reduced burdens for crop 2 and crop 3, whilst the total burden of nitrogen leaching and nitrous oxide emission associated with residue $\mathrm{N}$ is attributed to the legume crop 1 


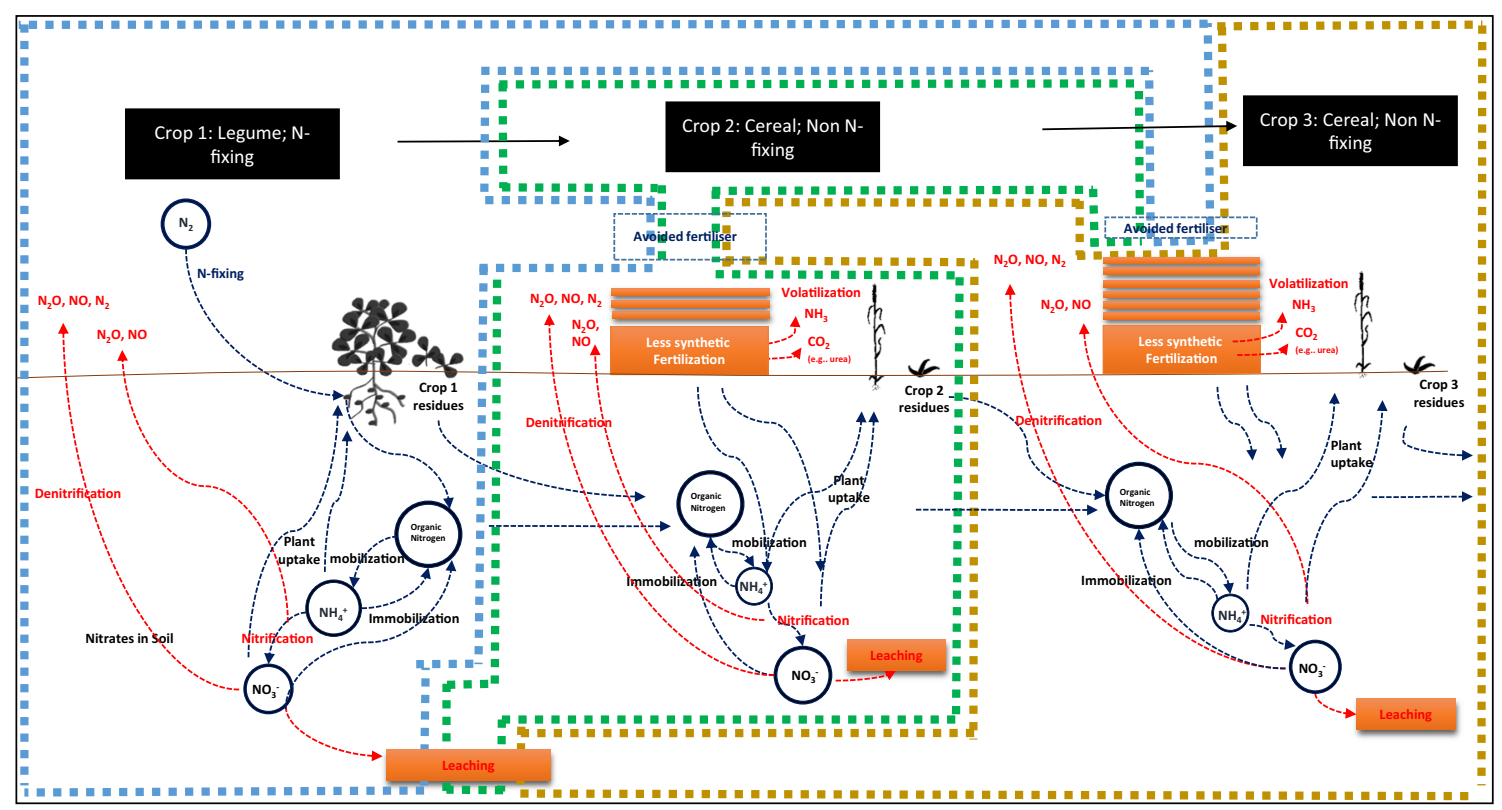

Fig. 3 Allocation methods for carryover nutrients can link the benefits of $\mathrm{N}$ fixation by crop 1 to reduced fertilizer requirements for the following crops in the rotation (crops 2 and 3), whilst burdens, such as leaching and

potential, the most encountered words were, in order of declining frequency: Energy, Eutrophication, Acidification, Ecotoxicity, Ozone, and Land Use (Table 1, Appendix 1).

Despite some legumes being irrigated, water use was rarely reported, being assessed in two studies only. Tuomisto et al. (2012) calculate the blue water in $\mathrm{km}^{3}$ of water consumed per year at a global scale through a planetary boundary method (Rockström et al. 2009). Rodrigues et al. (2016) mention the water and mineral resource depletion impact categories of the ILCD method (EC-JRC-IES 2011), but the authors do not present final results for this method. The UNEP consensus for water footprint recommended by the European Environmental Bureau (2018) - the WULCA method (Boulay et al. 2018) — assesses not only the amount of water used but also the scarcity potential at a watershed level. Use of WULCA was not encountered in any of the legume rotation studies.

Possible effects of legume intercropping systems include more efficient use of diesel because of a dual crop plant machine which sows two seeds instead of one after the other, combined with reduced $\mathrm{N}$ fertilisation, increased soil organic carbon and increased yield (Ashworth et al. 2015). When LCA is applied, the result of these efficiencies can be detected across multiple impact categories. Ashworth et al. (2015) analyse the environmental footprint of intercropping switchgrass with legumes (such as red clover) and calculate potential reduced impacts across ecotoxicity, acidification, eutrophication, global warming and photochemical ozone creation impact categories per ton of switchgrass. Most of the papers that refer to the land use impact category do not report the potential effects on soil quality (Milà i Canals et al. 2007) or nitrous oxide, will be distributed across all crops in the rotation, according to the selected allocation criteria by the LCA practitioner (e.g. mass, energy, biophysical)

biodiversity loss (Koellner and Scholz 2007, 2008; Chaudhary et al. 2015). The most common result found under land use is a simple metric of annual land occupation per $\mathrm{kg}$ grain produced $\left(\mathrm{m}^{2} \mathrm{yr}^{-1}\right)$, representing an inventory quantity rather than an impact per se.

\subsection{Summary of the types of LCA papers found in this review}

From the 70 articles analysed, it was possible to observe four primary types of study, according to the descriptions below.

I. Attributional LCA of a single crop in a rotation. These studies usually involve a simple LCA that sometimes includes experimental field emission data for the annual crop under study. This kind of study attributes $\mathrm{N}$ losses from residues to the studied crop (or to a following crop in a separate LCA of that crop), and usually only accounts for fertiliser-N avoidance implicitly for the studied (legume) crop. Details on rotation sequences are lacking in such LCA studies, and usually a simple FU is used, such as $\mathrm{kg}$ of specific product.

II. Attributional LCA of an entire rotation sequence with a simple aggregated FU. A common FU in this type of study is area over time or total dry matter production. When individual crops within the rotation are targeted for individual foot-printing under this type, allocation is required. In this last situation, the type I is integrated in the analysis.

III. Attributional LCA of an entire rotation sequence with a complex aggregated FU. This differs from type II studies 
in the complexity of the FU applied. Either a single FU encompasses multiple products and services delivered by a rotation or multiple FUs are applied to understand the implications of FU choice on rotation- and crop-level environmental efficiency. In this analysis, product substitution and inclusion of consequential scenarios can be found; however, the main modelling is done by an attributional LCA.

IV. Consequential LCA of introducing legumes into rotations, in which case all effects (marginal changes relative to the relevant pre-existing systems) can be attributed to the legume intervention.

From the 70 articles reviewed, more than half (56\%) were classified as type II. Only $24 \%$ were classified as type III, and only one article was classified as type IV. It is important to note that the search terms deliberately excluded many type I studies, as they have not mentioned 'rotation' or similar terms. Sensitivity analysis was rarely implemented across the studies, although some authors performed it for allocation methods (Table 1, Appendix 1).

\section{Discussion}

A crop rotation is multifunctional in that it produces a range of products for different purposes, such as animal feed, food for direct human consumption, energy or fibre. Introducing more legumes into European rotations has been proposed to improve the sustainability of European food and feed production (Watson et al. 2017). However, changes to rotation sequences, nutrient cycling and yields of crops within rotations mean that simple attributional LCA of the individual legume crops introduced into rotations does not adequately represent consequences for the environmental efficiency of rotations and related food systems, nor of individual crops within modified rotations. The solutions to better representation of rotationlevel effects of legume integration within LCA lie in either (i) attributing an environmental footprint to each product in the rotation, taking into account their interaction with the preceding and following crops; or (ii) defining a rotation level FU that can meaningfully represent multiple products (and services) delivered by rotations.

Of the four types of legume rotation LCA studies we categorised, type I is the most prevalent in the wider literature, but many such studies were filtered out of this particular review which focuses on rotations. Type I attributional LCA studies of discreet cultivation systems underpin widely used large-scale datasets (Blonk Consultants 2018; Moreno-Ruiz et al. 2018), and usually present footprints per $\mathrm{kg}$ of a crop (product) excluding rotation interactions. Type I LCA studies often ignore crop sequence interactions and draw the boundaries around a single cropping year - neglecting $\mathrm{N}$ fertiliser substitution benefits associated with legume residue $\mathrm{N}$ carryover, or representing this fertilisation credit in a reduced footprint for following (non-legume) crop(s). Meanwhile, leaching burdens are often attributed to the legumes. Thus, eutrophication and global warming burdens may be over-allocated to legumes, and under-allocated to following (cereal) crops (Cai et al. 2018). Type II studies involve assessment of whole rotation systems, often with a simple aggregating FU, often based on area over time. These were the most prevalent type of study reviewed here, but their interpretation has little significance from a production efficiency perspective - results may be used to draw conclusions about land management rather than the environmental efficiency of food production (Schau and Fet 2008). Thus, the most widely applied types of crop rotation LCA have important deficiencies that constrain their usefulness in informing more sustainable food production.

The amount of $\mathrm{N}$ carryover is strongly influenced by the incorporation of legumes in rotations (Kayser et al. 2010), whilst soil carbon content is influenced by specific management practices (Vestberg et al. 2002). These factors can significantly influence the environmental footprint of crops and derived products, but the type of allocation method employed determines the extent to which legumes are credited with fertiliser avoidance credits or leaching and $\mathrm{N}_{2} \mathrm{O}$ emission burdens (Naudin et al. 2014). Representing these factors is important to draw out potential effects of legumes in order to accurately inform stakeholders (Kayser et al. 2010), but typically requires field-scale modelling. Procedures to avoid allocation were encountered in this review. Peter et al. (2017) demonstrate the sensitivity of crop footprints to allocation methods through a legume cover crop case study. If alfalfa is not harvested but used as a green manure, the following crop can have a 7-8\% higher carbon footprint, and an 11$13 \%$ higher cumulative energy demand, but if the environmental impact is attributed to the harvested alfalfa crop, the legume crop (alfalfa in this example) has a 99\% larger carbon footprint, whilst the following crop has a $1 \%$ smaller footprint. In the first situation, alfalfa was first considered as a green manure, in other words, an input (nutrient provider) for the following crop (product), so its impact will count towards the succeeding crop footprint. In the second situation, alfalfa is considered as an individual crop, which contributes towards delivering the functional unit chosen by the practitioner (dry matter, energy, etc.), and therefore a product that has impacts associated with it. This approach is valid, but misses the potential multifunctionality of alfalfa in providing $\mathrm{N}$ fertilisation to the next crop (and the fact that a significant share of the leaching burden of alfalfa is biophysically related to this additional function). Other studies employed sub-process division to avoid allocation, considering rotations as a composition of annual crop cultivations (Nemecek et al. 2011; Prechsl et al. 2017; Goglio et al. 2018b). 
The CU (Brankatschk and Finkbeiner 2014), based on the digestible energy content of animal feed commodities, is a useful metric to aggregate multiple products from crop rotations. It does not affect the system boundaries and brings robustness to the LCA (Brankatschk and Finkbeiner 2015). However, the method is constrained to rotations primarily producing animal feeds, and to only one dimension of animal nutrition, and could reinforce the lock-in of European rotations to cereal dominance promoted by public polices, market demand and specialization based on agrochemical paradigms (Magrini et al. 2016). Therefore, using the CU might not be appropriate for studies focussing on the production of crops for direct human consumption, or indeed, for other uses, including protein-rich animal feeds of which there is a deficit within Europe (Watson et al. 2017). Other kinds of physical or biophysical allocations for rotation systems have been proposed. Martínez-Blanco et al. (2014) recommend N release as a parameter to allocate compost effects across crops, though this requires reliable estimation of mineralisation rates. Alternatively, the authors recommend allocation based on $\mathrm{N}$ (or phosphorus/potassium) uptake by the plant (MartínezBlanco et al. 2014). Knudsen et al. (2014b) also discuss different allocation methods for green manures and other catch crops. They suggest allocating based on $\mathrm{N}$ residual effect (as used by Tuomisto et al. (2012)) or by area. At present, no consensus for allocation methods in rotation systems has been achieved, which can lead to highly variable results and interpretation (Goglio et al. 2012; Martínez-Blanco et al. 2014; Brankatschk and Finkbeiner 2015). Sensitivity analysis is rarely applied in LCA studies. Given the variances outlined above, we propose that attributional LCA studies on legume cropping systems should apply sensitivity analyses at least to allocation methods.

Defining a FU for multifunctional cropping systems is challenging, since several products with different fates arise from these systems. No consensus definition of FU for legume rotations or intercropping systems was found from the types investigated in this review. However, awareness of the complexity of representing crops within crop rotations in LCA is increasing. Numerous authors have already applied multiple $\mathrm{FU}$ in order to understand systems from the perspective of an entire rotation (Nemecek et al. 2011; MacWilliam et al. 2014; Yang et al. 2014; Prechsl et al. 2017), especially in type III studies (Röös et al. 2016). Recent studies have proposed FUs that address the delivery of different functions (type III). For example, a multi-product approach has been proposed by Röös et al. (2016) and Costa et al. (2018). Costa et al. (2018) propose a FU based on a population demand for five food and energy products over a period of 7 years. This approach enables agricultural systems and rotations producing a range of different products to be compared in terms of their delivery of a proportion of overall human consumption. Allocation is fully avoided whilst the study captures important interactions across the years and elements (crops, trees and livestock) of rotations. The difference between the multivariable and land use approaches is that the multi-variable FU allows a comparison of a mix of products versus their independent production. In other words, this is a way of measuring the efficiency of integrating the products into a cropping system compared with producing them by their traditional mode, such as mono-cropping. As with the area-based FU, the disadvantage of such multifunctional FUs is that they do not provide a single product environmental footprint as required for labelling and evaluation of diet choice among other goals.

Final consumption and human nutrition FUs are often used to compare diet choices (Willett et al. 2019). However, due to the amount and complexity of data, most diet studies use international datasets rather than undertaking farm LCAs. To compare the nutritional footprints of alternative diets, potentially hundreds of footprints of food products are needed (Willett et al. 2019). To counter this situation, FUs that only cover one nutritional aspect are becoming common, such as protein content (MacWilliam et al. 2014; Karlsson et al. 2015). These FUs are not representative of other key nutrients. Furthermore, protein quality varies considerably depending on the source, with different amino acid compositions affecting human (and animal) nutrition (Sonesson et al. 2017; Leinonen et al. 2019). In developed countries, protein quality is less pertinent considering that the population largely over consumes protein, and net protein utilisation from various sources is similar for the adult population (WHO 2007). Notarnicola et al. (2017) recommend a careful analysis of nutritional values comprising not only fat, protein and energy but also other relevant nutrients. Van Dooren (2017) proposes a nutrition density unit as a FU, considering more than one nutritional aspect. However, Notarnicola et al. (2017) highlighted the limitation of such a FU when considering products that are consumed for a social aim, such as wine, beer, and coffee. Establishing human nutrition as a FU can bring additional limitations, especially when applying a cradle-to-gate boundary. First, it can be difficult to define nutritional composition for each product at the farm gate, in terms of specific elements (proteins, fatty acids, carbohydrates, vitamins, etc.) owing to the influence of soil type, climate and management (e.g. level of fertilisation) on concentrations of these elements. Additionally, nutritional FUs are usually intended for application to prepared foods ready to eat, following processing and cooking. In farm-level LCAs (most common approach for types I, II and III), nutritional aspects are difficult to define because the grains cultivated on the farm have different and sometimes unknown fates. The grains can supply different value chains across the food and feed industries requiring different levels of processing and therefore exhibiting different final nutritional values (FAO 2016). For example, cultivated chickpeas can be processed 
into flour, pasta, hummus, canned grains or just dried grains to be soaked and consumed. Therefore, assuming a nutritional value for chickpeas at farm level could be misrepresentative. Second, the FU could limit the boundaries of diverse agriculture systems, where co-products intended for energy or textile uses would need to be allocated off. Therefore, the best solution identified in this review is by Goglio et al. (2018a). Recognising the aforementioned limitations, they suggest a dual approach for crop rotations, simultaneously providing results for the rotation as a whole and for each product in the cropping system.

Assessing multiple impact categories can be also complicated in regional studies with wider boundaries, such as those integrating regional or international consequential analyses. In a consequential analysis, used by Knudsen et al. (2014a), the overall impact of producing more grain legumes in Europe was revealed to have a small climate benefit compared with importing soybeans. However, their study did not address nutrient carryover or other consequences at farm level, and only assessed GWP. One of the key potential advantages of introducing more legume cropping in Europe is the delivery of ecosystem services promoted by grain legumes (Karlsson et al. 2015). The choice of impact categories varies among the studies, and global warming potential is by far the most adopted impact category across all studies, which neglects potentially important co-benefits and trade-offs. For example, Costa et al. (2018) showed that complex crop-animal-tree rotation systems had a lower global warming potential but very high abiotic depletion (due to more use of animal feed compounds) compared with conventional (separate) systems. Regarding the calculators and tools designed to address LCA cropping system interactions, the Crop.LCA tool (Goglio et al. 2018b) is the only one that provides acidification potential, eutrophication and energy demand alongside global warming potential.

Following international guidelines such as ILCD (EC- JRC -IES 2011), or the more recent Product Environmental Footprint (European Commission 2018b), could be challenging for entire crop rotations owing to high data requirements. Impact categories and methods that assess soil quality, structure and biodiversity are not commonly reported in LCA (Gabel et al. 2016; Teixeira et al. 2016). Soil is often analysed at inventory level, e.g. accounting for the amount of land in the life cycle rather than a factor representing quality of land in terms of, e.g. SOC (Milà i Canals et al. 2007) or biodiversity (Koellner and Scholz 2007).

Product substitution and inclusion of consequential scenarios are found in studies performing product system expansion (type III). A common practice of product substitution is when organic fertilisation, including via legume residue incorporation, leads to credits from avoided synthetic fertilizer use (Nemecek et al. 2011; Brockmann et al. 2018). However, the inclusion of multiple avoided products and consequential analyses could be questionable due to the lack of standardisation and multiple speculative possibilities that can be evaluated (Mackenzie et al. 2017). Despite these limitations, the consequential approach has value in its ability to capture important indirect and intersystem effects (Ekvall and Weidema 2004). This is pertinent when the goal of LCA studies is to evaluate the consequences of introducing more legumes in to European rotations.

Consequential LCAs (type IV) are rarely applied to analyse legumes. However, the approach is pertinent when the goal is to understand cropping system changes at a regional scale. Compared with attributional LCA, consequential LCA could avoid the need for allocation through application of expanded system boundaries, whilst also capturing important potential (indirect) displacement effects in other supply chains. The lower yields of legume crops compared with cereals could mean that (cereal) production is displaced elsewhere, causing indirect land use change and international 'leakage' of environmental impacts (Styles et al. 2017). Meanwhile, legumes have an important role to play in diet change (providing quality plant protein to replace animal protein) and, as discussed, can enhance yields of subsequent crops. Therefore, legume deployment could also indirectly lead to carbon sequestration via, e.g. afforestation on spared land (Lamb et al. 2016). The balance of the aforementioned effects requires holistic evaluation of legume rotations and downstream (avoided) value chains. Consequential LCA has an important role to play here.

\section{Conclusion}

LCA is a key methodology to analyse the sustainability of food systems. This review finds that important interactions across years and crops are often neglected in LCA studies evaluating legume crops within rotations. Recent studies have demonstrated the importance of such interactions for product footprints (Brankatschk and Finkbeiner 2015; Nemecek et al. 2015; Goglio et al. 2018b). Thus, we recommend that LCA studies for legume cropping systems should (i) evaluate entire rotations and not just a single year of cultivation, at least including the crop following the legume; (ii) represent $\mathrm{N}$, ideally also carbon, cycling alongside other agronomic effects within rotations (further fundamental research and agronomic models may be required); (iii) for attributional studies, define at least two functional units, where one should encompass the multifunctional outputs of entire rotation sequences (e.g. by assessing human or animal nutritional potential) and the other should enable product footprints to be calculated. Sensitivity analyses are important to test the effect of different allocation methods on footprints. (iv) for consequential LCA studies, account for both agronomic changes in rotations and displacement effects within crop commodity markets following the introduction of legume crops; (v) include impact categories 
that reflect hotspots for agricultural production, beyond just global warming potential (carbon footprints). There is a need to develop clear guidelines for assessing crop rotations in their entirety, and the effect of introducing new crops into rotations, which could be undertaken by a task force comprising multiple agri-sustainability and LCA stakeholders. Any guidelines should complement and build on existing general LCA guidelines and address appropriate functional units, system boundaries, priority impact categories and allocation methods.

Funding information This research is supported by the TRUE project, funded by the EU Framework Programme for Research and Innovation H2020, Grant Agreement number 727973, and the Scottish Government's Strategic Research Development Programme.

Open Access This article is licensed under a Creative Commons Attribution 4.0 International License, which permits use, sharing, adaptation, distribution and reproduction in any medium or format, as long as you give appropriate credit to the original author(s) and the source, provide a link to the Creative Commons licence, and indicate if changes were made. The images or other third party material in this article are included in the article's Creative Commons licence, unless indicated otherwise in a credit line to the material. If material is not included in the article's Creative Commons licence and your intended use is not permitted by statutory regulation or exceeds the permitted use, you will need to obtain permission directly from the copyright holder. To view a copy of this licence, visit http://creativecommons.org/licenses/by/4.0/.

\section{References}

Alam MK, Bell RW, Biswas WK (2019) Decreasing the carbon footprint of an intensive rice-based cropping system using conservation agriculture on the Eastern Gangetic Plains. J Clean Prod 218:259-272. https://doi.org/10.1016/j.jclepro.2019.01.328

Ashworth AJ, Taylor AM, Reed DL, Allen FL, Keyser PD, Tyler DD (2015) Environmental impact assessment of regional switchgrass feedstock production comparing nitrogen input scenarios and legume-intercropping systems. J Clean Prod 87:227-234. https:// doi.org/10.1016/j.jclepro.2014.10.002

Barton L, Thamo T, Engelbrecht D, Biswas WK (2014) Does growing grain legumes or applying lime cost effectively lower greenhouse gas emissions from wheat production in a semi-arid climate? J Clean Prod 83:194-203. https://doi.org/10.1016/j.jclepro.2014.07.020

Begum N, Guppy C, Herridge D, Schwenke G (2014) Influence of source and quality of plant residues on emissions of $\mathrm{N} 2 \mathrm{O}$ and $\mathrm{CO} 2$ from a fertile, acidic Black Vertisol. Biol Fertil Soils 50:499-506. https:// doi.org/10.1007/s00374-013-0865-8

Behera KK, Alam A, Vats S et al (2012) Organic farming history and techniques. In: Agroecology and Strategies for Climate Change. Springer Netherlands, pp. 287-328

Bevilacqua M, Ciarapica FE, Mazzuto G, Paciarotti C (2014) Environmental analysis of a cotton yarn supply chain. J Clean Prod 82:154-165. https://doi.org/10.1016/j.jclepro.2014.06.082

Blonk Consultants (2018) Agri-footprint 4.0. 28

Boulay AM, Bare J, Benini L, Berger M, Lathuillière MJ, Manzardo A, Margni M, Motoshita M, Núñez M, Pastor AV, Ridoutt B, Oki T, Worbe S, Pfister S (2018) The WULCA consensus characterization model for water scarcity footprints: assessing impacts of water consumption based on available water remaining (AWARE). Int J Life Cycle Assess 23:368-378. https://doi.org/10.1007/s11367017-1333-8

Brankatschk G (2018) Modeling crop rotations and co-products in agricultural life cycle assessments, Modeling Crop Rotations and CoProducts in Agricultural Life Cycle Assessments. https://doi.org/10. 1007/978-3-658-23588-8.

Brankatschk G, Finkbeiner M (2014) Application of the cereal unit in a new allocation procedure for agricultural life cycle assessments. J Clean Prod 73:72-79. https://doi.org/10.1016/j.jclepro.2014.02.005

Brankatschk G, Finkbeiner M (2015) Modeling crop rotation in agricultural LCAs - challenges and potential solutions. Agric Syst 138:6676. https://doi.org/10.1016/j.agsy.2015.05.008

Brankatschk G, Finkbeiner M (2017) Crop rotations and crop residues are relevant parameters for agricultural carbon footprints. Agron Sustain Dev 37. https://doi.org/10.1007/s13593-017-0464-4

Brockmann D, Pradel M, Hélias A (2018) Agricultural use of organic residues in life cycle assessment: current practices and proposal for the computation of field emissions and of the nitrogen mineral fertilizer equivalent. Resour Conserv Recycl 133:50-62. https://doi. org/10.1016/j.resconrec.2018.01.034

Cai S, Pittelkow CM, Zhao X, Wang S (2018) Winter legume-rice rotations can reduce nitrogen pollution and carbon footprint while maintaining net ecosystem economic benefits. J Clean Prod 195:289300. https://doi.org/10.1016/j.jclepro.2018.05.115

Carof M, Godinot O (2018) A free online tool to calculate three nitrogenrelated indicators for farming systems. Agric Syst 162:28-33. https://doi.org/10.1016/j.agsy.2018.01.015

Carranca C, Oliveira A, Pampulha E, Torres MO (2009) Temporal dynamics of soil nitrogen, carbon and microbial activity in conservative and disturbed fields amended with mature white lupine and oat residues. Geoderma 151:50-59. https://doi.org/10.1016/j.geoderma. 2009.03.012

Carranza-Gallego G, Guzmán GI, García-Ruíz R, González de Molina M, Aguilera E (2018) Contribution of old wheat varieties to climate change mitigation under contrasting managements and rainfed Mediterranean conditions. J Clean Prod 195:111-121. https://doi. org/10.1016/j.jclepro.2018.05.188

Chaudhary A, Verones F, De Baan L, Hellweg S (2015) Quantifying land use impacts on biodiversity: combining species-area models and vulnerability indicators. Environ Sci Technol 49:9987-9995. https://doi.org/10.1021/acs.est.5b02507

Costa MP, Schoeneboom JC, Oliveira SA, Viñas RS, de Medeiros GA (2018) A socio-eco-efficiency analysis of integrated and nonintegrated crop-livestock-forestry systems in the Brazilian Cerrado based on LCA. J Clean Prod 171:1460-1471. https://doi.org/10. 1016/j.jclepro.2017.10.063

Dalgaard R, Halberg N, Kristensen IS, Larsen I (2006) Modelling representative and coherent Danish farm types based on farm accountancy data for use in environmental assessments. Agric Ecosyst Environ 117:223-237. https://doi.org/10.1016/j.agee.2006.04.002

De Vries SC, van de Ven GWJ, van Ittersum MK (2014) First or second generation biofuel crops in Brandenburg, Germany? A model-based comparison of their production-ecological sustainability. Eur J Agron 52:166-179. https://doi.org/10.1016/j.eja.2013.09.012

Drury CF, Tan CS (1995) Long-term (35 years) effects of fertilization, rotation and weather on corn yields. Can J Plant Sci 75:355-362. https://doi.org/10.4141/cjps95-060

Ekvall T, Weidema BP (2004) System boundaries and input data in consequential life cycle inventory analysis. In: International Journal of Life Cycle Assessment. Springer Verlag, pp. 161-171

Europe Commission (2018) The common agricultural policy at a glance | European Commission

European Commission (2018a) Report from the commission to the council and the European parliament on the development of plant proteins in the European Union 
European Commission (2018b) PEFCR - Product Environmental Footprint Category Rules Guidance. 1-142

European Commission (EC), Joint Research Centre (JRC), Institute for Environment Sustainability (IES) (2011) Reference Life Cycle Data System (ILCD) Handbook- Recommendations for Life Cycle Impact Assessment in the European context., First edit. Luxemburg: Publication Office of the European Union

European Environmental Bureau, Pro- GP, Commission E (2018) The EU Product Environmental Footprint ( PEF ) methodology what can it deliver and what not? An NGO viewpoint $1-10$

European Parliament (2009) Directive 2009/28/EC of the european parliament and of the council of 23 April 2009 on the promotion of the use of energy from renewable sources and amending and subsequently repealing Directives 2001/77/EC and 2003/30/EC

European Parliament (2018) European strategy for the promotion of protein crops. In: Eur. Parliam. RR $\backslash 1149642 \mathrm{EN}$

FAO (2016) Environmental performance of large ruminant supply chains. Guidelines for assessment, Rome

FAO (2018) Transforming food and agriculture to achieve the SDGs 20 interconnected actions to guide decision-makers. Rome

FAOStat (2016) Data dissemination | FAO | Food and Agriculture Organization of the United Nations

Foyer CH, Lam H, Nguyen HT et al (2016) Health and sustainable food production. Nat Publ Gr 2:1-10. https://doi.org/10.1038/nplants. 2016.112

Gabel VMM, Meier MSS, Köpke U, Stolze M (2016) The challenges of including impacts on biodiversity in agricultural life cycle assessments. J Environ Manag 181:249-260. https://doi.org/10.1016/j. jenvman.2016.06.030

Goglio P, Bonari E, Mazzoncini M (2012) LCA of cropping systems with different external input levels for energetic purposes. Biomass Bioenergy 42:33-42. https://doi.org/10.1016/j.biombioe.2012.03. 021

Goglio P, Brankatschk G, Knudsen MT, Williams AG, Nemecek T (2018a) Addressing crop interactions within cropping systems in LCA. Int J Life Cycle Assess 23:1735-1743. https://doi.org/10. 1007/s11367-017-1393-9

Goglio P, Smith WN, Worth DE, Grant BB, Desjardins RL, Chen W, Tenuta M, McConkey BG, Williams A, Burgess P (2018b) Development of Crop.LCA, an adaptable screening life cycle assessment tool for agricultural systems: a Canadian scenario assessment. J Clean Prod 172:3770-3780. https://doi.org/10.1016/j. jclepro.2017.06.175

Grant T, Eady SJ, Cruypenninck HP, et al (2019) AusLCI methodology for developing life cycle inventory for Australian agriculture. Lifecycles

Grönroos J, Seppälä J, Voutilainen P et al (2006) Energy use in conventional and organic milk and rye bread production in Finland. Agric Ecosyst Environ 117:109-118. https://doi.org/10.1016/j.agee.2006. 03.022

Hauggaard-Nielsen H, Lachouani P, Knudsen MT, Ambus P, Boelt B, Gislum R (2016) Productivity and carbon footprint of perennial grass-forage legume intercropping strategies with high or low nitrogen fertilizer input. Sci Total Environ 541:1339-1347. https://doi. org/10.1016/j.scitotenv.2015.10.013

Hedayati M, Brock PM, Nachimuthu G, Schwenke G (2019) Farm-level strategies to reduce the life cycle greenhouse gas emissions of cotton production: an Australian perspective. J Clean Prod 212:974-985. https://doi.org/10.1016/j.jclepro.2018.11.190

Hoffman E, Cavigelli MA, Camargo G, Ryan M, Ackroyd VJ, Richard TL, Mirsky S (2018) Energy use and greenhouse gas emissions in organic and conventional grain crop production: accounting for nutrient inflows. Agric Syst 162:89-96. https://doi.org/10.1016/j.agsy. 2018.01.021

Hunt ND, Hill JD, Liebman M (2017) Reducing freshwater toxicity while maintaining weed control, profits, and productivity: effects of increased crop rotation diversity and reduced herbicide usage. Environ Sci Technol 51:1707-1717. https://doi.org/10.1021/acs. est.6b04086

ISO 14040 (2006) ISO - ISO 14040:2006 - Environmental management - life cycle assessment - Principles and framework

ISO 14044 (2006) ISO - ISO 14044:2006/Amd 1:2017 - Environmental management - life cycle assessment — Requirements and guidelines - Amendment 1

Karlsson H, Ahlgren S, Strid I, Hansson PA (2015) Faba beans for biorefinery feedstock or feed? Greenhouse gas and energy balances of different applications. Agric Syst 141:138-148. https://doi.org/ 10.1016/j.agsy.2015.10.004

Kayser M, Müller J, Isselstein J (2010) Nitrogen management in organic farming: comparison of crop rotation residual effects on yields, $\mathrm{N}$ leaching and soil conditions. Nutr Cycl Agroecosyst 87:21-31. https://doi.org/10.1007/s10705-009-9309-0

Klöpffer W (2003) Life-cycle based methods for sustainable product development. Int J Life Cycle Assess 8:157-159

Knudsen MT, Hermansen JE, Olesen JE et al (2014a) Climate impact of producing more grain legumes in Europe. Proc 9th Int Conf Life Cycle Assess Agri-Food Sect (LCA Food 2014), San Fr California, USA, 8-10 October, 2014 641-646

Knudsen MT, Meyer-Aurich A, Olesen JE, Chirinda N, Hermansen JE (2014b) Carbon footprints of crops from organic and conventional arable crop rotations - using a life cycle assessment approach. J Clean Prod 64:609-618. https://doi.org/10.1016/j.jclepro.2013.07. 009

Koellner T, Scholz RW (2007) Assessment of land use impacts on the natural environment: part 1: an analytical framework for pure land occupation and land use change. Int J Life Cycle Assess 12:16-23. https://doi.org/10.1065/lca2006.12.292.1

Koellner T, Scholz RW (2008) Assessment of land use impacts on the natural environment: part 2: generic characterization factors for local species diversity in Central Europe. Int J Life Cycle Assess 13:3248. https://doi.org/10.1065/lca2006.12.292.2

Kristensen T, Mogensen L, Knudsen MT, Hermansen JE (2011) Effect of production system and farming strategy on greenhouse gas emissions from commercial dairy farms in a life cycle approach. Livest Sci 140:136-148. https://doi.org/10.1016/j.livsci.2011.03.002

Lamb A, Green R, Bateman I, Broadmeadow M, Bruce T, Burney J, Carey P, Chadwick D, Crane E, Field R, Goulding K, Griffiths H, Hastings A, Kasoar T, Kindred D, Phalan B, Pickett J, Smith P, Wall E, zu Ermgassen EKHJ, Balmford A (2016) The potential for land sparing to offset greenhouse gas emissions from agriculture. Nat Clim Chang 6:488-492. https://doi.org/10.1038/nclimate2910

Laudicina VA, Novara A, Gristina L, Badalucco L (2014) Soil carbon dynamics as affected by long-term contrasting cropping systems and tillages under semiarid Mediterranean climate. Appl Soil Ecol 73: 140-147. https://doi.org/10.1016/j.apsoil.2013.09.002

Leinonen I, Iannetta PPM, Rees RM, Russell W, Watson C, Barnes AP (2019) Lysine supply is a critical factor in achieving sustainable global protein economy. Front Sustain Food Syst 3:1-11. https:// doi.org/10.3389/fsufs.2019.00027

Mackenzie SG, Leinonen I, Kyriazakis I (2017) The need for co-product allocation in the life cycle assessment of agricultural systems - is "biophysical" allocation progress? Int J Life Cycle Assess 22:128 137. https://doi.org/10.1007/s11367-016-1161-2

MacWilliam S, Wismer M, Kulshreshtha S (2014) Life cycle and economic assessment of Western Canadian pulse systems: the inclusion of pulses in crop rotations. Agric Syst 123:43-53. https://doi.org/10. 1016/j.agsy.2013.08.009

Magrini MBB, Anton M, Cholez C et al (2016) Why are grain-legumes rarely present in cropping systems despite their environmental and nutritional benefits? Analyzing lock-in in the French agrifood system. Ecol Econ 126:152-162. https://doi.org/10.1016/j.ecolecon. 2016.03.024 
Martínez-Blanco J, Rieradevall J, Antón A, Muñoz P (2014) Multifunctionality-solving approaches of compost application in crop rotations. J Clean Prod 64:384-395. https://doi.org/10.1016/j. jclepro.2013.08.014

Meyer-Aurich A, Weersink A, Janovicek K, Deen B (2006) Cost efficient rotation and tillage options to sequester carbon and mitigate $\mathrm{GHG}$ emissions from agriculture in Eastern Canada. Agric Ecosyst Environ 117:119-127. https://doi.org/10.1016/j.agee.2006.03.023

Milà i Canals L, Romanyà J, Cowell SJ (2007) Method for assessing impacts on life support functions (LSF) related to the use of 'fertile land' in life cycle assessment (LCA). J Clean Prod 15:1426-1440. https://doi.org/10.1016/j.jclepro.2006.05.005

Moreno-Ruiz E, Valsasina L, Brunner F, et al (2018) Documentation of changes implemented in ecoinvent Data 3.5. Zürich, Switzerland

Naudin C, Van Der Werf HMG, Jeuffroy MH, Corre-Hellou G (2014) Life cycle assessment applied to pea-wheat intercrops: a new method for handling the impacts of co-products. J Clean Prod 73:80-87. https://doi.org/10.1016/j.jclepro.2013.12.029

Nemecek T, Erzinger S (2005) Modelling representative life cycle inventories for Swiss arable crops. Int J Life Cycle Assess 10:68-76. https://doi.org/10.1065/lca2004.09.181.8

Nemecek T, von Richthofen JS, Dubois G, Casta P, Charles R, Pahl H (2008) Environmental impacts of introducing grain legumes into European crop rotations. Eur J Agron 28:380-393. https://doi.org/ 10.1016/j.eja.2007.11.004

Nemecek T, Huguenin-Elie O, Dubois D, Gaillard G, Schaller B, Chervet A (2011) Life cycle assessment of Swiss farming systems: II. Extensive and intensive production. Agric Syst 104:233-245. https://doi.org/10.1016/j.agsy.2010.07.007

Nemecek T, Hayer F, Bonnin E, Carrouée B, Schneider A, Vivier C (2015) Designing eco-efficient crop rotations using life cycle assessment of crop combinations. Eur J Agron 65:40-51. https://doi.org/ 10.1016/j.eja.2015.01.005

Nikièma P, Rothstein DE, Min DH, Kapp CJ (2011) Nitrogen fertilization of switchgrass increases biomass yield and improves net greenhouse gas balance in northern Michigan, U.S.A. Biomass Bioenergy 35: 4356-4367. https://doi.org/10.1016/j.biombioe.2011.08.006

Notarnicola B, Sala S, Anton A, McLaren SJ, Saouter E, Sonesson U (2017) The role of life cycle assessment in supporting sustainable agri-food systems: a review of the challenges. J Clean Prod 140: 399-409. https://doi.org/10.1016/j.jclepro.2016.06.071

Ostle NJ, Levy PE, Evans CD, Smith P (2009) Land Use Policy UK land use and soil carbon sequestration. 274-283. https://doi.org/10.1016/ j.landusepol.2009.08.006

Peter C, Specka X, Aurbacher J, Kornatz P, Herrmann C, Heiermann M, Müller J, Nendel C (2017) The MiLA tool: modeling greenhouse gas emissions and cumulative energy demand of energy crop cultivation in rotation. Agric Syst 152:67-79. https://doi.org/10.1016/j. agsy.2016.12.008

Pirlo G, Terzano G, Pacelli C, Abeni F, Carè S (2014) Carbon footprint of milk produced at Italian buffalo farms. Livest Sci 161:176-184. https://doi.org/10.1016/j.livsci.2013.12.007

Plaza-Bonilla D, Nolot JM, Raffaillac D, Justes E (2017) Innovative cropping systems to reduce $\mathrm{N}$ inputs and maintain wheat yields by inserting grain legumes and cover crops in southwestern France. Eur J Agron 82:331-341. https://doi.org/10.1016/j.eja.2016.05.010

Plaza-Bonilla D, Nogué-Serra I, Raffaillac D, Cantero-Martínez C, Justes É (2018) Carbon footprint of cropping systems with grain legumes and cover crops: a case-study in SW France. Agric Syst 167:92-102. https://doi.org/10.1016/j.agsy.2018.09.004

Prechsl UE, Wittwer R, van der Heijden MGA, Lüscher G, Jeanneret P, Nemecek T (2017) Assessing the environmental impacts of cropping systems and cover crops: life cycle assessment of FAST, a long-term arable farming field experiment. Agric Syst 157:39-50. https://doi.org/10.1016/j.agsy.2017.06.011
Preissel S, Reckling M, Schläfke N, Zander P (2015) Magnitude and farm-economic value of grain legume pre-crop benefits in Europe: a review. F Crop Res 175:64-79. https://doi.org/10.1016/j.fcr.2015. 01.012

Rebitzer G, Ekvall T, Frischknecht R et al (2004) Life cycle assessment part 1: framework, goal and scope definition, inventory analysis, and applications

Reckling M, Hecker JM, Bergkvist G, Watson CA, Zander P, Schläfke N, Stoddard FL, Eory V, Topp CFE, Maire J, Bachinger J (2016) A cropping system assessment framework - evaluating effects of introducing legumes into crop rotations. Eur J Agron 76:186-197. https://doi.org/10.1016/j.eja.2015.11.005

Rees RM, Bingham IJ, Baddeley JA, Watson CA (2005) The role of plants and land management in sequestering soil carbon in temperate arable and grassland ecosystems. Geoderma 128:130-154. https:// doi.org/10.1016/j.geoderma.2004.12.020

Reinsch T, Loges R, Kluß C, Taube F (2018) Soil \& Tillage Research Renovation and conversion of permanent grass-clover swards to pasture or crops : effects on annual $\mathrm{N} 2 \mathrm{O}$ emissions in the year after ploughing. Soil Tillage Res 175:119-129. https://doi.org/10.1016/j. still.2017.08.009

Rockström J, Steffen W, Noone K, Persson Å, Chapin FS III, Lambin EF, Lenton TM, Scheffer M, Folke C, Schellnhuber HJ, Nykvist B, de Wit CA, Hughes T, van der Leeuw S, Rodhe H, Sörlin S, Snyder PK, Costanza R, Svedin U, Falkenmark M, Karlberg L, Corell RW, Fabry VJ, Hansen J, Walker B, Liverman D, Richardson K, Crutzen P, Foley JA (2009) Planetary boundaries: exploring the safe operating space for humanity. Nature 461:472-475. https://doi.org/10. $1038 / 461472$ a

Rodrigues J, Houzelot V, Ferrari F, Echevarria G, Laubie B, Morel JL, Simonnot MO, Pons MN, (2016) Life cycle assessment of agromining chain highlights role of erosion control and bioenergy. J. Clean. Prod. 139, 770-778. https://doi.org/10.1016/j.jclepro. 2016.08.110

Röös E, Patel M, Spångberg J (2016) Producing oat drink or cow's milk on a Swedish farm - environmental impacts considering the service of grazing, the opportunity cost of land and the demand for beef and protein. Agric Syst 142:23-32. https://doi.org/10.1016/j.agsy.2015. 11.002

Schau EM, Fet AM (2008) LCA studies of food products as background for environmental product declarations. Int J Life Cycle Assess 13: 255-264

Smith P (2004) Carbon sequestration in croplands: the potential in Europe and the global context. Eur J Agron 20:229-236. https://doi.org/10. 1016/j.eja.2003.08.002

Smith P (2014) Do grasslands act as a perpetual sink for carbon? Glob Chang Biol 20:2708-2711. https://doi.org/10.1111/gcb.12561

Sonesson U, Davis J, Flysjö A, Gustavsson J, Witthöft C (2017) Protein quality as functional unit - a methodological framework for inclusion in life cycle assessment of food. J Clean Prod 140:470-478. https://doi.org/10.1016/j.jclepro.2016.06.115

Stoate C, Boatman ND, Borralho RJ, Carvalho CR, De Snoo GR, Eden P (2001) Ecological impacts of arable intensification in Europe. J Environ Manage 63, 337-365. https://doi.org/10.1006/jema.2001. 0473

Styles D, Gonzalez-Mejia A, Moorby J, Foskolos A, Gibbons J (2017) Climate mitigation by dairy intensification depends on intensive use of spared grassland. Glob Chang Biol 24:681-693. https://doi.org/ 10.1111/gcb.13868

Teixeira RFMFM, De Souza DMM, Curran MPP et al (2016) Towards consensus on land use impacts on biodiversity in LCA: UNEP/ SETAC life cycle initiative preliminary recommendations based on expert contributions. J Clean Prod 112:4283-4287. https://doi. org/10.1016/j.jclepro.2015.07.118

Tosti G, Benincasa P, Farneselli M, Tei F, Guiducci M (2014) Barleyhairy vetch mixture as cover crop for green manuring and the 
mitigation of N leaching risk. Eur J Agron 54:34-39. https://doi.org/ 10.1016/j.eja.2013.11.012

Tuomisto HL, Hodge ID, Riordan P, MacDonald DW (2012) Exploring a safe operating approach to weighting in life cycle impact assessment - a case study of organic, conventional and integrated farming systems. J Clean Prod 37:147-153. https://doi.org/10.1016/j.jclepro. 2012.06.025

Van Dooren C (2017) Proposing the nutrient density unit as the functional unit in LCAs of foods. Int Conf Life Cycle Assess Food 2016:1-10

Vestberg M, Kukkonen S, Saari K et al (2002) Cropping system impact on soil quality determinants. Agric Food Sci Finl 11:311-328. https://doi.org/10.23986/afsci.5733

Watson CA, Reckling M, Preissel S et al (2017) Grain legume production and use in European agricultural systems. Adv Agron 144:235-303. https://doi.org/10.1016/bs.agron.2017.03.003

WHO - World Health Organization (2007) Protein and amino acid requirements in human nutrition Report of a Joint WHO/FAO/UNU Expert Consultation, no. 935. WHO technical report series

Willett W, Rockström J, Loken B, Springmann M, Lang T, Vermeulen S, Garnett T, Tilman D, DeClerck F, Wood A, Jonell M, Clark M, Gordon LJ, Fanzo J, Hawkes C, Zurayk R, Rivera JA, de Vries W, Majele Sibanda L, Afshin A, Chaudhary A, Herrero M, Agustina R, Branca F, Lartey A, Fan S, Crona B, Fox E, Bignet V, Troell M, Lindahl T, Singh S, Cornell SE, Srinath Reddy K, Narain S, Nishtar S, Murray CJL (2019) Food in the
Anthropocene: the EAT-lancet Commission on healthy diets from sustainable food systems. Lancet 393:447-492

WWF (2014) The growth of soy impacts and solutions

Yang X, Gao W, Zhang M, Chen Y, Sui P (2014) Reducing agricultural carbon footprint through diversified crop rotation systems in the North China Plain. J Clean Prod 76:131-139. https://doi.org/10. 1016/j.jclepro.2014.03.063

Yao Z, Zhang D, Yao P, Zhao N, Liu N, Zhai B, Zhang S, Li Y, Huang D, Cao W, Gao Y (2017) Coupling life-cycle assessment and the RothC model to estimate the carbon footprint of green manurebased wheat production in China. Sci Total Environ 607-608: 433-442. https://doi.org/10.1016/j.scitotenv.2017.07.028

Zander P, Amjath-Babu TS, Preissel S, Reckling M, Bues A, Schläfke N, Kuhlman T, Bachinger J, Uthes S, Stoddard F, Murphy-Bokern D, Watson C (2016) Grain legume decline and potential recovery in European agriculture: a review. Agron Sustain Dev 36. https://doi. org/10.1007/s13593-016-0365-y

Zucali M, Bacenetti J, Tamburini A, Nonini L, Sandrucci A, Bava L (2018) Environmental impact assessment of different cropping systems of home-grown feed for milk production. J Clean Prod 172: 3734-3746. https://doi.org/10.1016/j.jclepro.2017.07.048

Publisher's note Springer Nature remains neutral with regard to jurisdictional claims in published maps and institutional affiliations. 